\title{
Fume Formation from Oxidation of Liquid SiMn Alloy
}

\author{
${\text { Yan } \mathrm{Ma}^{1} \text { (D) Ida Kero }}^{2} \cdot$ Gabriella Tranell $^{1}$
}

Received: 7 February 2017/Revised: 18 April 2017/Published online: 16 May 2017

(C) The Author(s) 2017. This article is an open access publication

\begin{abstract}
Thermally generated fumes from the production of manganese ferroalloys are mostly composed of metallic oxides generated due to reaction between hightemperature molten metal and ambient oxygen in the air. In the current study, the fume characteristics (particle morphology, compositions and particle size distribution) from the exposure of a SiMn alloy under an impinging air jet, in the temperature range $1400-1700{ }^{\circ} \mathrm{C}$, were experimentally investigated. Combinations of manganese- and manganese/silicon oxide particles were found in the system, displaying both crystalline and amorphous structures. The governing generation mechanisms of fume from both a thermodynamic and a kinetic perspective are discussed.
\end{abstract}

Keywords Silicomanganese $\cdot$ Oxidation · Fume $\cdot$ Morphology

\section{Introduction}

Reducing fugitive emissions from metallurgical processes, in order to improve in-door working conditions and reduce local community impact, has received increasing efforts and investments in the past decade. In the manganese ferroalloy industry, fugitive emissions are generated during material handling and transportation, sinter production, electricity generation, smelting, refining and casting processes [1]. The International Manganese Institute (IMnI) has carried out a life cycle analysis (LCA) project of global manganese alloy production which is a cradle-to-gate study with

Yan Ma

yan.ma@ntnu.no

1 Norwegian University of Science and Technology (NTNU), Alfred Getz vei 2, 7491 Trondheim, Norway

2 SINTEF Materials and Chemistry, Alfred Getz vei 2, 7465 Trondheim, Norway 
boundaries spanning all mining, smelting and associated upstream processes involved in the production of $1 \mathrm{~kg}$ of manganese ferroalloy. Table 1 shows the total fume emissions, both mechanically and thermally generated, for one $\mathrm{kg}$ of manganese alloy product, as determined in their study [1]. The primary production processes contribute a significant fraction of these total fume emissions.

During the tapping, refining and casting of manganese ferroalloys, thermally generated fumes are released to the working environment. A limited number of studies have been focused on characterization of particulate emissions from such production processes [2-4]. The fumes are mostly composed of metallic oxides and formed in a reaction between high-temperature molten metal and ambient oxygen in the air [5]. Kero et al. [4] performed an elemental analysis of fumes collected in a SiMn alloy production plant, using EDX coupled to an electron microscope. The major elements found were $\mathrm{Si}, \mathrm{Mn}$ and $\mathrm{O}$, and minor elements detected were $\mathrm{Mg}$, $\mathrm{Ca}, \mathrm{Al}$ and $\mathrm{K}$, while trace elements were $\mathrm{Na}, \mathrm{Fe}, \mathrm{Zn}, \mathrm{Cu}$ and $\mathrm{Cl}$. The fume collected from production sites is, however, generally a combination of particulate matter from different process sources-for which the chemical composition, phase distribution and morphology of particles vary greatly. As such, a detailed understanding of the correlation between process conditions and fume characteristics cannot be obtained from such fume samples.

Very few papers addressing fume generation mechanisms, thermochemistry and kinetics in manganese ferroalloy production, have been published [5-7]. Preliminary work on the active oxidation of main elements Si and Mn from liquid SiMn alloy under an impinging air jet in the temperature range $1400-1600{ }^{\circ} \mathrm{C}$, has been undertaken by the current authors [8]. In addition, the minor/trace elements behaviour in fume from liquid SiMn alloy generated under the same impinging air jet in the temperature range of $1450-1700{ }^{\circ} \mathrm{C}$ is recently published [9].

The aim of the current study was to explore, in more detail, the fuming rate and fume characteristics from liquid SiMn, kept at varying temperatures under an impinging air jet, with the objective of increasing the understanding of underlying oxidation/fuming mechanisms of the $\mathrm{Si}-\mathrm{Mn}$ system. This information will aid in the design of more effective fume mitigation and collection systems for the industry.

\section{Theoretical Background}

\section{Manganese}

As an extension of the early work by Wagner [10], Turkdogan [11] described the fume formation by vapourization of liquid metals. His work showed that vapourization of metals may be sped up by the reaction between metal vapour

Table 1 Total mass of suspended particles in air per $\mathrm{kg}$ of manganese alloy product [1]

\begin{tabular}{lllll}
\hline Category & SiMn & High C FeMn & Ref. FeMn & Average Mn alloy \\
\hline Particulate matter $(\mathrm{g})$ & 11.5 & 8.5 & 8.0 & 9.6 \\
\hline
\end{tabular}


and oxygen in the atmosphere, when an oxide mist is formed above the metal boundary layer. This is the so-called oxidation-enhanced vapourization process. This theory can be applied to several metal systems, including Mn.

Manganese exhibits a high vapour pressure at elevated temperatures. A few studies have been carried out with respect to the evaporative reaction of manganese during the oxygen refining process for ferromanganese alloys $[12,13]$. You and coauthors [12], for example, defined an "apparent vapourization coefficient $(\beta)$ " to describe the loss of manganese through oxidation during the industrial refining process to account for the fact that the ferromanganese composition and temperature change continuously during the refining cycle.

$$
\beta=10^{4.776} \frac{\left(\frac{Q_{\mathrm{O}_{2}(\mathrm{~B})}}{Q_{\mathrm{O}_{2}(\mathrm{~B})}+Q_{\text {inert(B) }}}\right)^{2.604}\left(\frac{Q_{\mathrm{O}_{2}(\mathrm{~T})}}{Q_{\mathrm{O}_{2}(\mathrm{~T})}+Q_{\mathrm{O}_{2}(\mathrm{~B})}}\right)^{1.811}}{[\% C]^{0.608}}
$$

where $Q_{\mathrm{O}_{2}}$ and $Q_{\text {inert }}$ are the flow rates of oxygen and inert gas $\left(\mathrm{Nm}^{3} / \mathrm{min}\right)$, and the subscripts (B) and (T) denote bottom and top blowing, respectively.

You et al. found that the apparent vapourization coefficient of manganese is affected by the oxygen mixing ratio in the bottom blowing gas and the fraction of top blown oxygen during the oxygen refining of high carbon ferromanganese melts. Lee et al. [13] have also found that the rate of manganese vapourization is controlled by the flux of excess oxygen towards the metal surface when the manganese vapour pressure is very low, but once the manganese vapour pressure becomes high, it is controlled by the mass transfer of manganese vapour through the diffusion boundary layer above the metal surface.

Manganese may form several oxides, of which only monoxide $(\mathrm{MnO})$ is stable at high temperatures. $\mathrm{MnO}_{2}$ and $\mathrm{Mn}_{2} \mathrm{O}_{3}$ dissociate in solid state to lower oxides when heated-even in the air [14]. Possible reactions that may happen during the oxidation of liquid manganese with their associated Gibbs free energy of reaction (valid from 0 to $2000{ }^{\circ} \mathrm{C}$ ), calculated by FactSage 7.0 using FactPS and FToxide databases [15], are shown below:

$$
\operatorname{Mn}(\mathrm{l})=\operatorname{Mn}(\mathrm{g}) \quad \Delta G^{\mathrm{o}}(\mathrm{kJ})=225.61-0.1124 T\left({ }^{\circ} \mathrm{C}\right)
$$

$$
\begin{aligned}
& \operatorname{Mn}(\mathrm{g})+1 / 2 \mathrm{O}_{2}(\mathrm{~g})=\mathrm{MnO}(\mathrm{l} / \mathrm{s}) \\
& \Delta G_{1}^{\mathrm{o}}(\mathrm{kJ})=-556.27+0.1715 T\left({ }^{\circ} \mathrm{C}\right) \Delta G_{\mathrm{s}}^{\mathrm{o}}(\mathrm{kJ})=-603.64+0.1972 T\left({ }^{\circ} \mathrm{C}\right)
\end{aligned}
$$

$$
\begin{gathered}
3 \mathrm{MnO}(\mathrm{s})+1 / 2 \mathrm{O}_{2}(\mathrm{~g})=\mathrm{Mn}_{3} \mathrm{O}_{4}\left(\mathrm{~s}_{1}\right) \quad \Delta G^{\mathrm{o}}(\mathrm{kJ})=-194.32+0.1222 T\left({ }^{\circ} \mathrm{C}\right) \\
2 \mathrm{Mn}(\mathrm{g})+3 / 2 \mathrm{O}_{2}(\mathrm{~g})=\mathrm{Mn}_{2} \mathrm{O}_{3}\left(\mathrm{~s}_{2}\right) \quad \Delta G^{\mathrm{o}}(\mathrm{kJ})=-1358.3+0.4907 T\left({ }^{\circ} \mathrm{C}\right) \\
2 / 3 \mathrm{Mn}_{3} \mathrm{O}_{4}\left(\mathrm{~s}_{1}\right)+1 / 6 \mathrm{O}_{2}(\mathrm{~g})=\mathrm{Mn}_{2} \mathrm{O}_{3}\left(\mathrm{~s}_{2}\right) \quad \Delta G^{\mathrm{o}}(\mathrm{kJ})=-21.459+0.0148 T\left({ }^{\circ} \mathrm{C}\right)
\end{gathered}
$$




$$
1 / 2 \mathrm{Mn}_{2} \mathrm{O}_{3}\left(\mathrm{~s}_{2}\right)+1 / 4 \mathrm{O}_{2}(\mathrm{~g})=\mathrm{MnO}_{2}(\mathrm{~s}) \quad \Delta G^{\mathrm{o}}(\mathrm{kJ})=-24.599+0.0522 T\left({ }^{\circ} \mathrm{C}\right)
$$

$\mathrm{Mn}_{3} \mathrm{O}_{4}\left(\mathrm{~s}_{1}\right)$ and $\mathrm{Mn}_{2} \mathrm{O}_{3}\left(\mathrm{~s}_{2}\right)$ represent tetragonal (low-temperature) $\mathrm{Mn}_{3} \mathrm{O}_{4}$ and cubic (high-temperature) $\mathrm{Mn}_{2} \mathrm{O}_{3}$, respectively.

The Mn-O phase diagram, as calculated by FactSage 7.0 using FactPS and FToxide databases [15], is shown in Fig. 1. As shown by the phase diagram, MnO monoxide is stable at high temperatures, even at higher oxygen partial pressures, while tetragonal $\mathrm{Mn}_{3} \mathrm{O}_{4}$ and the higher oxide species $\mathrm{Mn}_{2} \mathrm{O}_{3}$ and $\mathrm{MnO}_{2}$ are stable mainly at lower temperatures. As such, it is expected that fume formed at high temperatures (liquid alloy temperatures $\geq 1400{ }^{\circ} \mathrm{C}$ ) would consist mainly of $\mathrm{MnO}$, which may in turn oxidize to higher $\mathrm{Mn}$ oxides in more oxygen-rich atmospheres during cooling.

\section{Silicon}

Wagner's theory [10] describes the principles of active and passive oxidation of silicon. It is widely accepted that the active oxidation of liquid silicon is a process consisting of two steps: the formation of volatile $\mathrm{SiO}$ gas, which is oxidized into $\mathrm{SiO}_{2}$ liquid (due to the exothermic nature of the reaction) and cooled to fume particles in the second step [10, 16]. Hinze and Graham [17] found that the ratelimiting step for the oxidation process is the oxygen diffusion through the boundary layer. Næss et al. [18-20] have concluded that as the boundary layer of $\mathrm{SiO}$ gas is thinner than the $\mathrm{O}_{2}$ gas boundary layer, the oxygen may travel through the $\mathrm{SiO}$ gas boundary layer and reach the liquid metal surface. They also found that the gas velocity above the metal surface is the rate-determining parameter for the mass

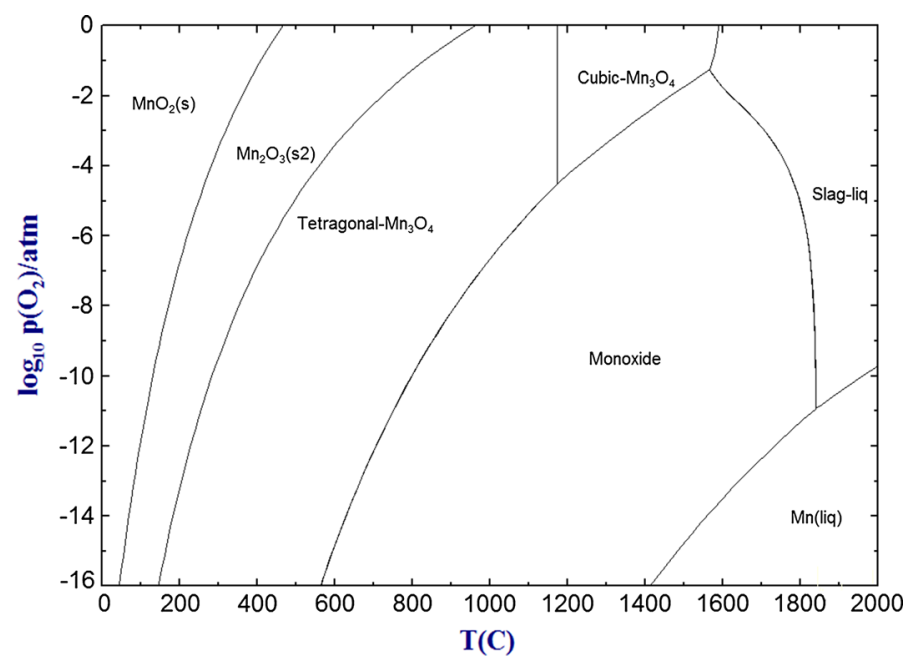

Fig. 1 Calculated equilibrium relations in $\mathrm{Mn}-\mathrm{O}$ system [15] 
transport of oxygen to the silicon surface, affecting the fuming rate [18]. The two reactions in the oxidation process, with their associated Gibbs free energy of reaction (valid from 0 to $2000{ }^{\circ} \mathrm{C}$ ), are shown below, $\mathrm{SiO}_{2}\left(\mathrm{~s}_{6}\right)$ means $\mathrm{SiO}_{2}\left(\mathrm{Crs} \_\mathrm{h}\right)$ :

$$
\begin{gathered}
\mathrm{Si}(\mathrm{l})+1 / 2 \mathrm{O}_{2}(\mathrm{~g})=\mathrm{SiO}(\mathrm{g}) \quad \Delta G^{\mathrm{o}}(\mathrm{kJ})=-168.25-0.0507 T\left({ }^{\circ} \mathrm{C}\right) \\
\mathrm{SiO}(\mathrm{g})+1 / 2 \mathrm{O}_{2}(\mathrm{~g})=\mathrm{SiO}_{2}\left(1 / \mathrm{s}_{6}\right) \\
\Delta G_{1}^{\mathrm{o}}(\mathrm{kJ})=-720.89+0.2468 T\left({ }^{\circ} \mathrm{C}\right) \Delta G_{\mathrm{s}}^{\mathrm{o}}(\mathrm{kJ})=-729.16+0.2516 T\left({ }^{\circ} \mathrm{C}\right)
\end{gathered}
$$

The $\mathrm{Si}-\mathrm{O}$ phase diagram, as calculated by FactSage 7.0 using FactPS and FToxide databases [15], is shown in Fig. 2. $\mathrm{SiO}_{2}$ is a stable compound at all temperatures, as shown in the phase diagram. Active oxidation leads to $\mathrm{SiO}$ gas formation. At $1500{ }^{\circ} \mathrm{C}, \mathrm{SiO}_{2}$ becomes stable when a surface oxygen pressure $P_{\mathrm{O}_{2}}$ reaches a maximum of $2.86 \times 10^{-18}$ atm; a higher $P_{\mathrm{O}_{2}}$ value will lead to the passivation oxidation of the silicon surface [19].

\section{SiMn Alloy}

During the oxidation and fuming from the liquid SiMn alloy surface, as previously hypothesized [8], two oxygen-competing mechanisms may be operative in parallel: a direct oxidation of $\mathrm{Mn}$ vapour and a two-step oxidation of silicon. Reactions involving species containing both $\mathrm{Si}$ and $\mathrm{Mn}$ may also occur from a thermodynamic perspective, with possible reactions listed below $\left(\Delta G^{\mathrm{o}}\right.$, valid from 0 to $\left.2000{ }^{\circ} \mathrm{C}\right)$ :

$$
\begin{gathered}
\mathrm{SiO}_{2}(\mathrm{l})+2 \mathrm{MnO}(\mathrm{l})=\mathrm{Mn}_{2} \mathrm{SiO}_{4}(\mathrm{~s}) \quad \Delta G^{\mathrm{o}}(\mathrm{kJ})=-151.28+0.0616 T\left({ }^{\circ} \mathrm{C}\right) \\
\mathrm{SiO}_{2}\left(\mathrm{~s}_{6}\right)+2 \mathrm{MnO}(\mathrm{l})=\mathrm{Mn}_{2} \mathrm{SiO}_{4}(\mathrm{~s}) \quad \Delta G^{\mathrm{o}}(\mathrm{kJ})=-143.03+0.0568 T\left({ }^{\circ} \mathrm{C}\right)
\end{gathered}
$$

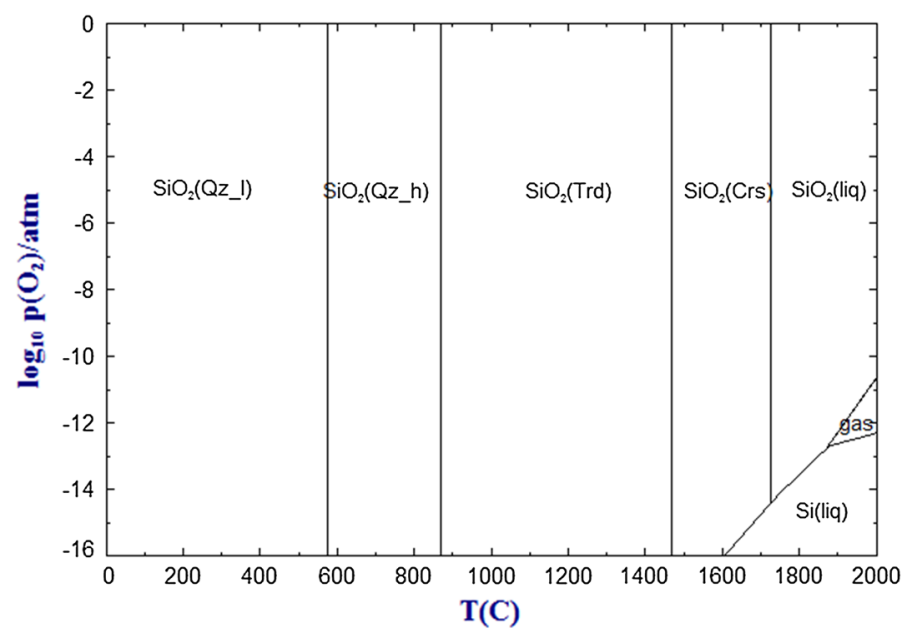

Fig. 2 Calculated equilibrium relations in Si-O system [15] 


$$
\begin{gathered}
\mathrm{SiO}_{2}(\mathrm{l})+2 \mathrm{MnO}(\mathrm{s})=\mathrm{Mn}_{2} \mathrm{SiO}_{4}(\mathrm{~s}) \quad \Delta G^{\mathrm{o}}(\mathrm{kJ})=-56.567+0.0102 T\left({ }^{\circ} \mathrm{C}\right) \\
\mathrm{SiO}_{2}\left(\mathrm{~s}_{6}\right)+2 \mathrm{MnO}(\mathrm{s})=\mathrm{Mn}_{2} \mathrm{SiO}_{4}(\mathrm{~s}) \quad \Delta G^{\mathrm{o}}(\mathrm{kJ})=-48.297+0.0054 T\left({ }^{\circ} \mathrm{C}\right) \\
1.5 \mathrm{O}_{2}(\mathrm{~g})+\mathrm{SiO}(\mathrm{g})+2 \mathrm{Mn}(\mathrm{g})=\mathrm{Mn}_{2} \mathrm{SiO}_{4}(\mathrm{~s}) \\
\Delta G^{\mathrm{o}}(\mathrm{kJ})=-1984.7+0.6514 T\left({ }^{\circ} \mathrm{C}\right)
\end{gathered}
$$

\section{Experimental Procedures}

The experimental set-up is shown in Fig. 3, the same as used in the study by Kero et al. [8]. A standard grade SiMn alloy, composed of $68.03 \mathrm{wt} \% \mathrm{Mn}, 17.58 \mathrm{wt} \% \mathrm{Si}$ and $2 \mathrm{wt} \% \mathrm{C}$ as well as minor and trace elements, and dry synthetic air with a gas flow rate of $3 \mathrm{~L} / \mathrm{min}$ were used for the investigation. The experiments were carried out at seven different temperatures between 1400 and $1700{ }^{\circ} \mathrm{C}$; the experimental matrix is shown in Table 2. Three reference experiments were carried out to detect whether there is fume formed without synthetic air blowing over the melt.

After the experiments, the fume was collected at three sites: the so-called transition tube, the cooler and the filter. The majority of fume was collected from the filter. The deposition temperatures at the three sites are also shown in the figure; there was a significant temperature drop inside the transition tube, from about $600{ }^{\circ} \mathrm{C}$ at the transition tube entry point to around $200{ }^{\circ} \mathrm{C}$ at the point of connection to the cooler. In the cooler, the temperature dropped further to $26^{\circ} \mathrm{C}$, and the filter kept constant at almost the same temperature.

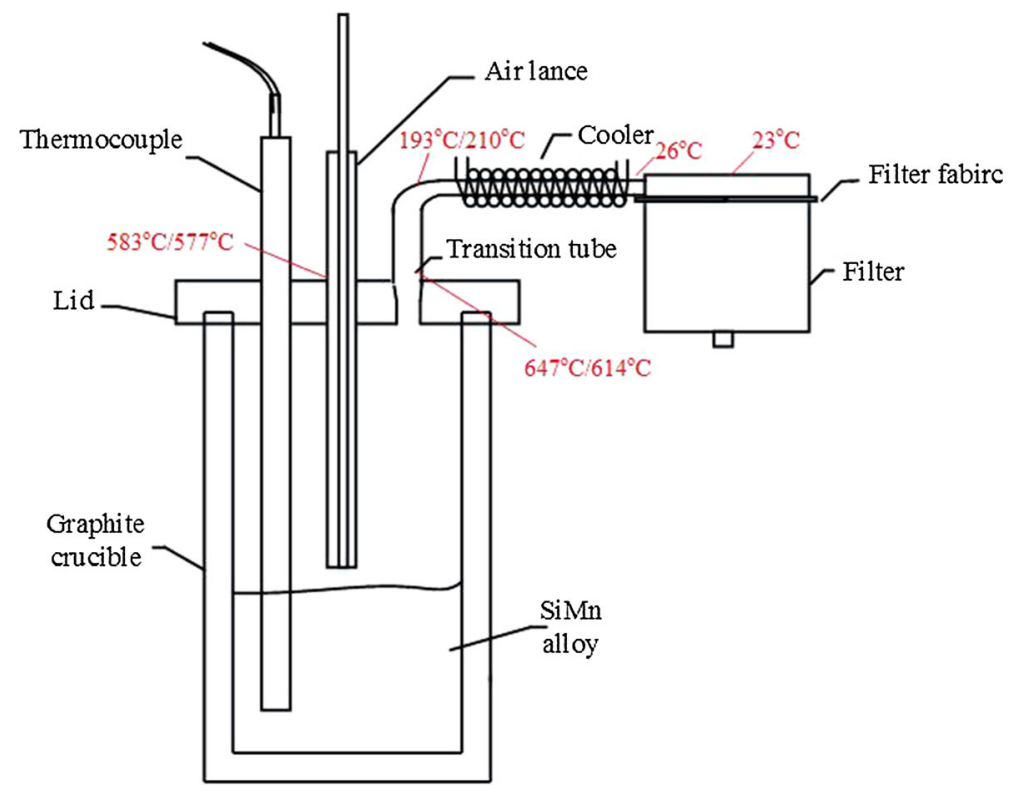

Fig. 3 The experimental set-up 
Table 2 Experimental matrix

\begin{tabular}{llll}
\hline Gas & Temp $\left({ }^{\circ} \mathrm{C}\right)$ & No of exp. & Comment \\
\hline None & 1400 & 1 & References, holding time 60 min \\
None & 1550 & 1 & References, holding time 20 min \\
None & 1700 & 1 & References, holding time 15 min \\
Synth. air & 1400 & 2 & Holding times: 60 and 80 min \\
Synth. air & 1450 & 2 & Holding times: 40 and 57 min \\
Synth. air & 1500 & 2 & Holding times: 20 min \\
Synth. air & 1550 & 2 & Holding times: 20 and 25 min \\
Synth. air & 1600 & 2 & Holding times: 20 and 25 min \\
Synth. air & 1650 & 3 & Holding times: 20 min \\
Synth. air & 1700 & 2 & Holding times: 15 and 13 min \\
\hline
\end{tabular}

The graphite crucible used for the experiments will lead to formation of $\mathrm{CO}(\mathrm{g})$, as previously reported [6]. The presence of $\mathrm{CO}$, altering the oxygen partial pressure of the system, will to some extent affect the thermochemistry and thus potentially the kinetics of the fuming process.

The total amount of fume generated in each experiment is measured and calculated as mass flux $J_{\mathrm{m}}$,

$$
J_{\mathrm{m}}=\frac{m}{A t}
$$

$J_{\mathrm{m}}$ is the mass flux, $m$ is the mass of fume generated, $A$ is the surface area of the molten metal, and $t$ is the holding time of the experiment.

The mass fluxes of $\mathrm{Si}$ and $\mathrm{Mn}$, respectively, were calculated by employing the average mass flux, together with the average concentrations of $\mathrm{Si}$ and $\mathrm{Mn}$ obtained from ICP-MS analysis of the fume at different temperatures, see Eqs. (16) and (17):

$$
\begin{gathered}
J_{\mathrm{Si}}=J_{\mathrm{m}}^{\mathrm{avg}} \times C_{\mathrm{si}} \\
J_{\mathrm{Mn}}=J_{\mathrm{m}}^{\mathrm{avg}} \times C_{\mathrm{Mn}}
\end{gathered}
$$

$J_{\mathrm{Si}}$ and $J_{\mathrm{Mn}}$ are the mass flux of $\mathrm{Si}$ and $\mathrm{Mn}$ for each temperature, respectively, $J_{\mathrm{m}}^{\text {avg }}$ is the average mass flux, and $C_{\mathrm{si}}$ and $C_{\mathrm{Mn}}$ are the average concentrations of $\mathrm{Si}$ and $\mathrm{Mn}$ in the fume, respectively.

The fume collected from the three different sites during the experiments was characterized by scanning electron microscopy (SEM) with energy-dispersive X-ray spectrometry (EDS), X-ray diffractometry (XRD), transmission electron microscopy (TEM) and inductively coupled plasma mass spectrometry (ICP-MS). Particle size estimations were based on Brunauer-Emmett-Teller surface adsorption (BET) and laser diffraction (LD), assuming an average density model. 


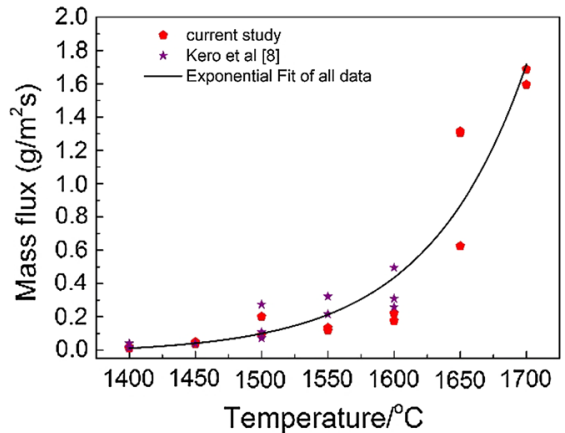

(a)

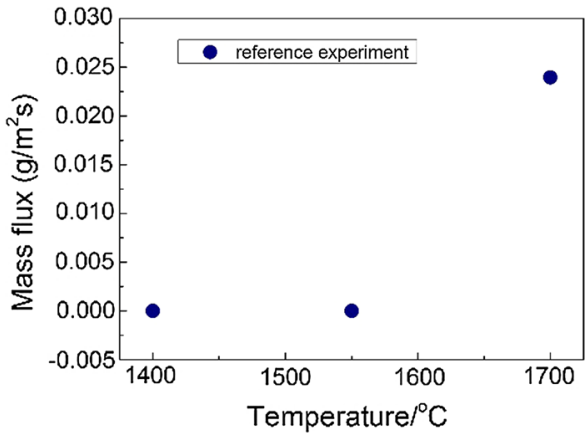

(b)

Fig. 4 Measured mass flux of fume over the SiMn alloy as a function of temperature, a with air blown on the liquid alloy surface, $\mathbf{b}$ reference experiment without air blown on the liquid alloy surface. Note the different y-scales

\section{Results and Discussion}

\section{Mass Flux}

The total mass flux calculated from the experimental data in this study and the prestudy [8] is shown in Fig. 4. These two series of data are plotted as a function of liquid alloy temperature. The total mass flux increases exponentially with temperature. The exponential fitting of all data combined has an $R^{2}$ value of 0.88 .

There was no measurable mass of fume formed in the reference experiments at 1400 and $1550{ }^{\circ} \mathrm{C}$, but for the $1700{ }^{\circ} \mathrm{C}$ reference experiment, there was a small amount of dark fume in the filter. The mass flux obtained from the reference experiments is illustrated in Fig. 4b. Similar dark colour fumes were also observed to have formed in the initial stages at 1650 and $1700{ }^{\circ} \mathrm{C}$ experiments with synthetic air blowing.

The mass fluxes of Si and Mn, according to Eqs. (16) and (17) for different temperatures, are shown in Fig. 5a, respectively. Both fluxes increase significantly above $1600{ }^{\circ} \mathrm{C}$, which is consistent with the dark colour fumes observed above $1600{ }^{\circ} \mathrm{C}$; the mass flux of Mn increases much faster than that of Si.

The concentrations of Si and Mn were determined by ICP-MS, and the results are illustrated in Fig. 5b. For ICP-MS, each sample was analysed three times, so that a relative standard deviation (RSD) value could also be obtained. Any analysis with an RSD value above $10 \%$ was considered unreliable. However, in all the reliable data, there was still as large as $5 \mathrm{wt} \%$ deviation in the data for the same sample, even in the analytical parallels. The concentration of $\mathrm{Mn}$ in the fume decreases with temperatures, while the concentration of Si seems to exhibit maxima at $1600{ }^{\circ} \mathrm{C}$. The limiting factor for the oxidation of $\mathrm{Si}$ is expected to be the oxygen diffusion onto the liquid metal surface. Diffusion generally increases with temperature, so this is likely governing the behaviour below $1600{ }^{\circ} \mathrm{C}$. Above $1600{ }^{\circ} \mathrm{C}$, the diffusion may have been inhibited by the high $\mathrm{Mn}$ vapour pressure. The decreasing concentration 


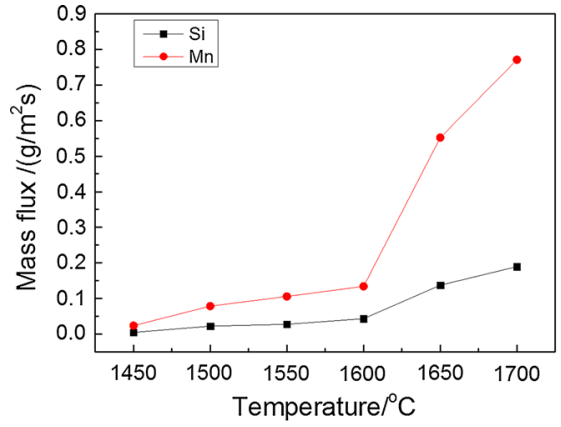

(a)

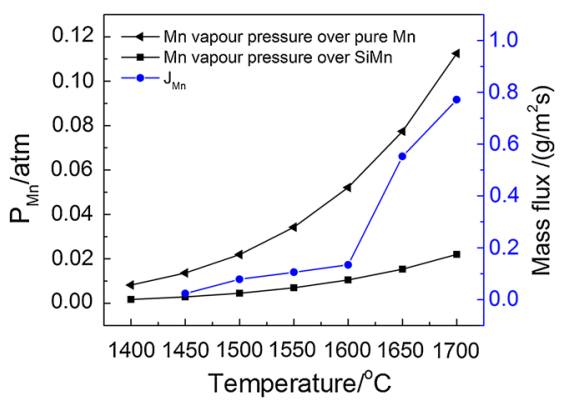

(c)

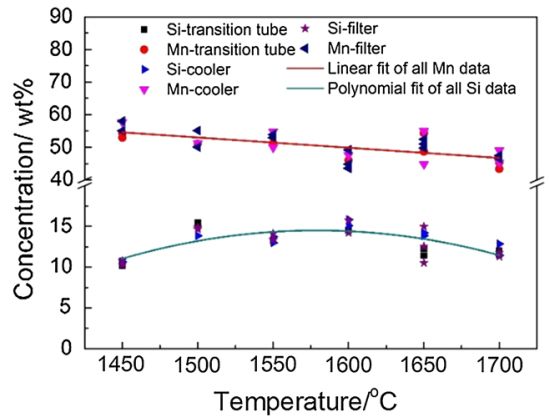

(b)

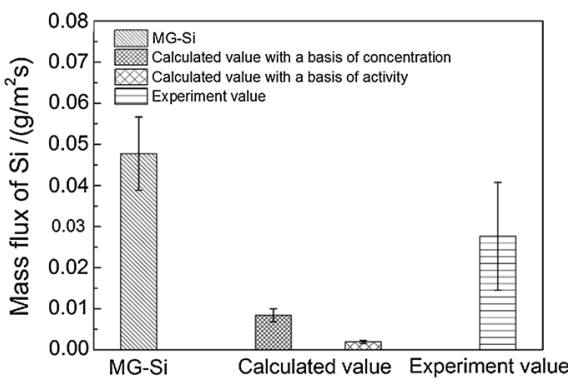

(d)

Fig. 5 a Mass flux of $\mathrm{Si}$ and $\mathrm{Mn}$ in the fume as a function of temperature. b Concentrations of $\mathrm{Si}$ and $\mathrm{Mn}$ in the fume as a function of temperature. c Mn vapour pressures and mass flux of $\mathrm{Mn}$ in the fume. d Comparison on mass flux of Si from oxidation of MG-Si and SiMn alloy at $1550{ }^{\circ} \mathrm{C}$

of Mn may be explained by the relatively higher oxidation level, the presence of more $\mathrm{Si}$ and more trace elements [9] in the fume.

A comparison between the $\mathrm{Mn}$ vapour pressure over pure $\mathrm{Mn}$, the $\mathrm{Mn}$ vapour pressure over a standard grade SiMn alloy (as calculated by FactSage 7.0, using FactPS and FTlite databases [15]) and the Mn mass flux ( $\mathrm{J}_{\mathrm{Mn}}$, see Eq. 17) is shown in Fig. 5c. While the calculated Mn vapour pressure over both pure Mn and SiMn alloy as well as the measured mass flux increases with temperature, the Mn mass flux increases very rapidly at temperatures above $1600{ }^{\circ} \mathrm{C}$, similarly to pure $\mathrm{Mn}$, indicating a change in mechanisms and/or kinetics at this temperature. This is consistent with the observations by You et al. [11].

The Si mass flux from the SiMn alloy (as calculated from experimental data according to Eq. 16) compared with the Si flux from a pure Si melt at $1550{ }^{\circ} \mathrm{C}$ as measured by Næss et al. [18], is shown in Fig. 5d. In addition, Fig. 5d also shows two calculated, theoretical mass fluxes of $\mathrm{Si}$, based on the concentration of $\mathrm{Si}$ and the activity of Si in the SiMn alloy, respectively, see Eqs. (18) and (19).

$$
\begin{gathered}
J_{\mathrm{Si}}^{\mathrm{c}}=J_{\mathrm{Si}} \times C_{\mathrm{Si}}^{\mathrm{c}} \\
J_{\mathrm{Si}}^{\mathrm{a}}=J_{\mathrm{Si}} \times a_{\mathrm{Si}}
\end{gathered}
$$


$J_{\mathrm{Si}}^{\mathrm{c}}$ and $J_{\mathrm{Si}}^{\mathrm{a}}$ are estimated value through the concentration of $\mathrm{Si}$ and activity of $\mathrm{Si}$ in the SiMn alloy, respectively, $C_{\mathrm{Si}}^{\mathrm{c}}$ is the concentration of $\mathrm{Si}$ in the $\mathrm{SiMn}$ alloy, $a_{\mathrm{Si}}$ is the activity of $\mathrm{Si}$ in the liquid $\mathrm{SiMn}$ alloy, and $J_{\mathrm{Si}}$ is the mass flux of Si from a pure Si melt.

The values were estimated based on the concentration $(17.58 \mathrm{wt} \%$ ) and the activity (0.04) of $\mathrm{Si}$ in the standard grade SiMn alloy, respectively. As shown in Fig. 5d, the experimentally measured Si mass flux is one order of magnitude larger than calculated comparative values. It is, in fact, more close to the experimental values from pure $\mathrm{Si}$. It seems that the presence of $\mathrm{Mn}$ vapour above the melt may enhance the oxidation of $\mathrm{Si}$ in the SiMn alloy, as compared to pure Si.

\section{Fume Particle Morphology, Compositions and Size Distributions}

\section{Reference Experiment at $1700{ }^{\circ} \mathrm{C}$}

The dark fume formed at $1700{ }^{\circ} \mathrm{C}$ reference experiment was analysed by SEM with EDS. A typical SEM micrograph is shown in Fig. 6a, and the corresponding X-ray diffractogram is shown in Fig. 6b. The fume particles are compact agglomerates composed of mainly crystalline components $\mathrm{Mn}_{5} \mathrm{Si}_{3}$ and $\mathrm{MnS}$. There is also a certain amount of pure $\mathrm{Mn}$ and potentially some pure $\mathrm{Si}$. The presence of some amorphous components is manifested by the somewhat broadened peaks in the X-ray diffractogram.

\section{Fume Morphology and Particle Size Distribution}

As shown in Fig. 7, different typical fume morphologies were identified by SEM. The micrographs in Fig. 7a show both some irregular and spherical particles, characteristic of fumes generated at the lowest temperatures, 1400 and $1450{ }^{\circ} \mathrm{C}$. The irregular shapes include chain-like, cubic, cones and other shapes. Fume particles in Fig. $7 \mathrm{~b}$ consist of irregular-shaped particles with small particles around, originating

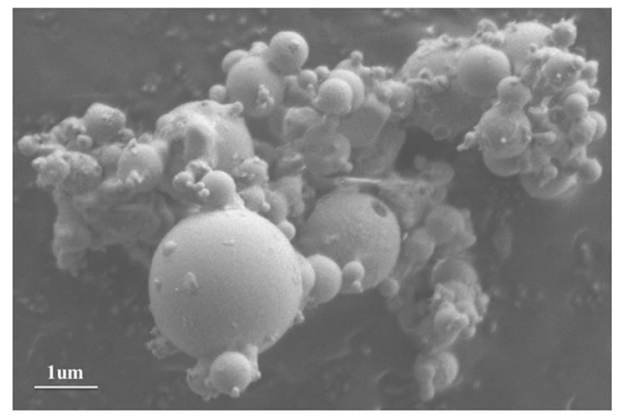

(a)

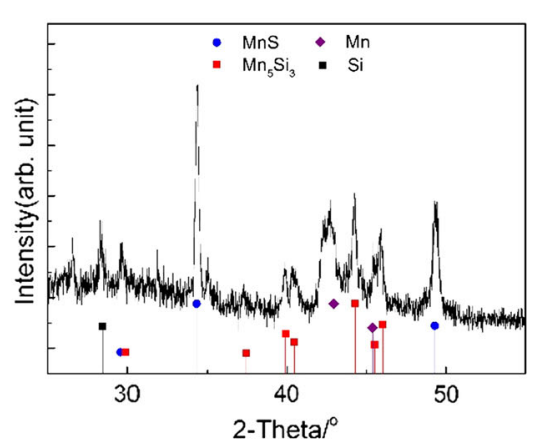

(b)

Fig. 6 Morphology and composition of fume at $1700{ }^{\circ} \mathrm{C}$ reference experiment, a morphology of fume, b compositions as observed by XRD 


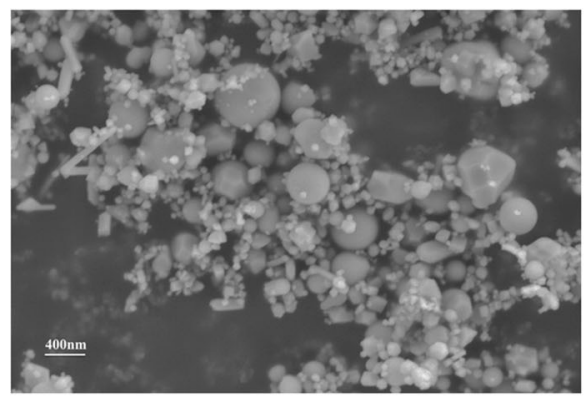

(a)

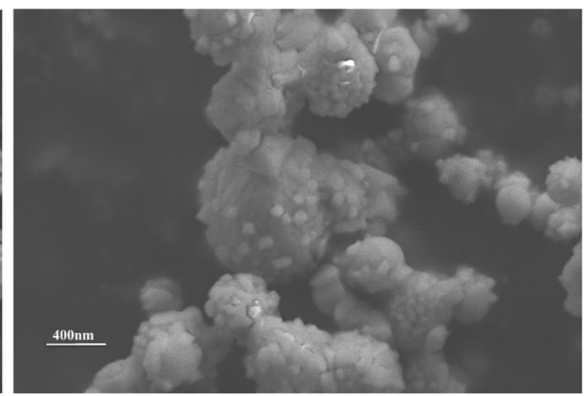

(b)

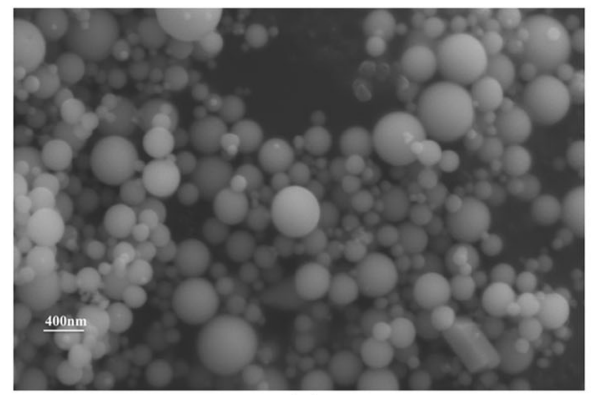

(c)

Fig. 7 Typical morphologies of fume at different temperatures, as illustrated by SEM. a Typical filter fume at 1400 and $1450{ }^{\circ} \mathrm{C}$, b fume generated at $1450{ }^{\circ} \mathrm{C}$ and collected from the transition tube, $\mathbf{c}$ typical fume generated at $1500-1700{ }^{\circ} \mathrm{C}$

from the $1450{ }^{\circ} \mathrm{C}$ transition tube fume sample. The fume particles in Fig. 7c are mainly spherical particles with only a very small amount of irregular particles. This is typical for fume generated in the higher temperature range $1500-1700{ }^{\circ} \mathrm{C}$.

The most common morphology encountered in these experiments is, by far, small spheres of various sizes with very smooth surfaces, exemplified in Fig. 7c. The micrographs in Fig. 7b illustrate the particle growth process.

Particle size distributions (PSD) of the fume were determined by laser diffraction (LD, Fig. 8a) and by visual evaluation of SEM images (Fig. 8b). The specific surface area of the particles was also measured by BET analysis, and the results are shown in Table 3 . The surface area can be used to estimate an average particle size if a single particle shape can be assumed. In this case, however, the particles formed at and below $1450{ }^{\circ} \mathrm{C}$ consist of both irregular and spherical shapes and therefore such size calculations might be misleading.

Airborne fume particles are typically found as agglomerates. In this article, the terms "protoparticles", "primary" and "secondary" agglomerates are used as described by Dingsøyr et al. [21]. Primary agglomerates are stabilized by strong forces and/or material bridges between protoparticles which can, sometimes, be seen by electron microscopy. The secondary agglomerates are sometimes referred to as aggregates in the literature, and these are less stable clusters of protoparticles held together by weak van der Waals forces. 


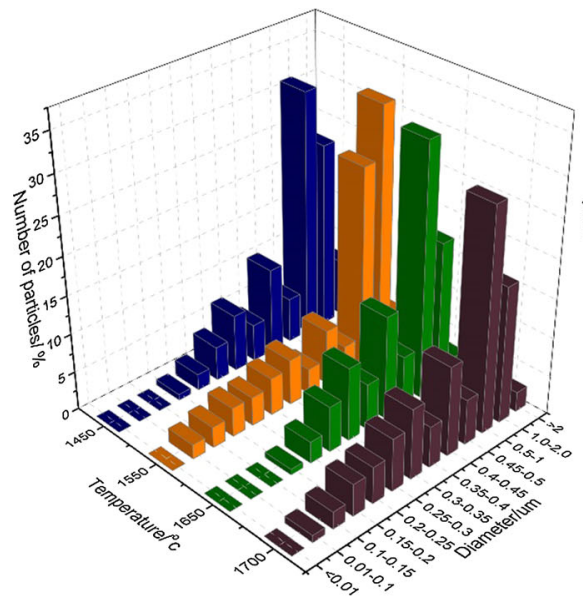

(a)

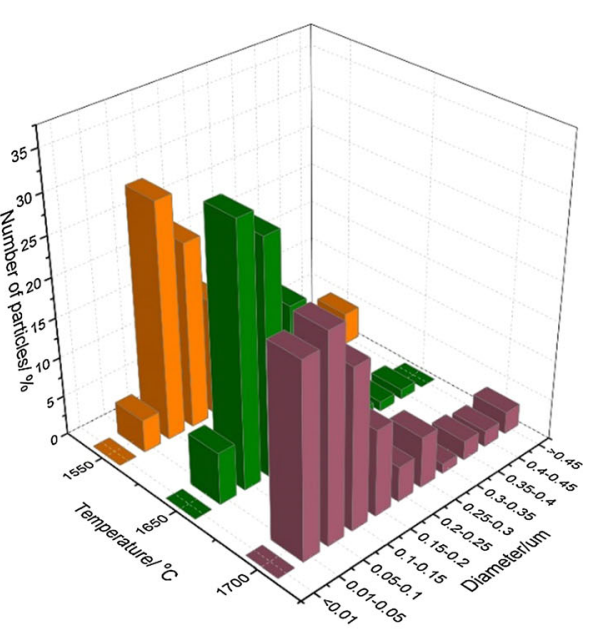

(b)

Fig. 8 Particle size distribution of typical SiMn filter fume at different temperatures, a obtained by LD, b obtained by SEM

Table 3 BET surface area of SiMn filter fume

\begin{tabular}{ll}
\hline Sample & Surface area $\left(\mathrm{m}^{2} / \mathrm{g}\right)$ \\
\hline $1450{ }^{\circ} \mathrm{C}$ filter fume & 4.85 \\
$1550{ }^{\circ} \mathrm{C}$ filter fume & 4.23 \\
$1650{ }^{\circ} \mathrm{C}$ filter fume & 5.18 \\
$1700{ }^{\circ} \mathrm{C}$ filter fume & 6.13 \\
\hline
\end{tabular}

The particle size distribution results in Fig. 8a, b are different because they measure different entities. The LD distribution indicates the size of agglomerates present in the fume samples. As shown in Fig. 8a, the majority of these agglomerates have an aerodynamic diameter smaller than $2 \mu \mathrm{m}$. The SEM image, however, does not provide any means to distinguish between free protoparticles (if such were to exist) and secondary agglomerates. Hence, only the protoparticle size distribution can be obtained/visualized by SEM. The protoparticle size distributions of the filter fumes from three different temperatures are shown in Fig. 8b. These protoparticles are all smaller than $0.5 \mu \mathrm{m}$.

\section{Phase Compositions}

All the fumes collected from different fume deposition positions under the 7 different temperatures were characterized by XRD. XRD can only detect crystalline substances as they give rise to sharp peaks. Any presence of amorphous matter is indicated by a broad "hump" in the diffractogram baseline.

Typical XRD diffraction patterns of fumes from the three deposition sites at different temperatures are shown in Fig. 9, and different phases identified are listed 


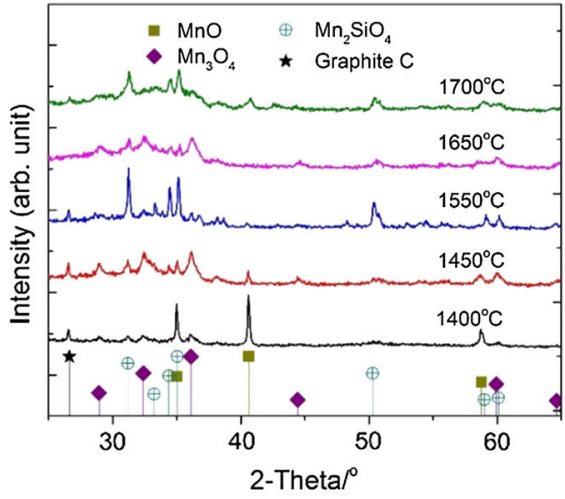

(a)

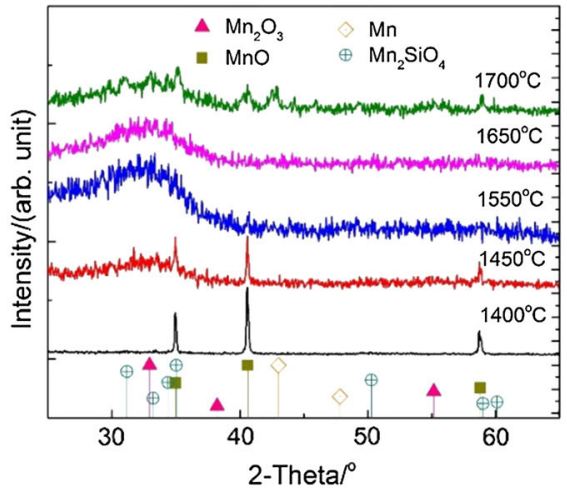

(b)

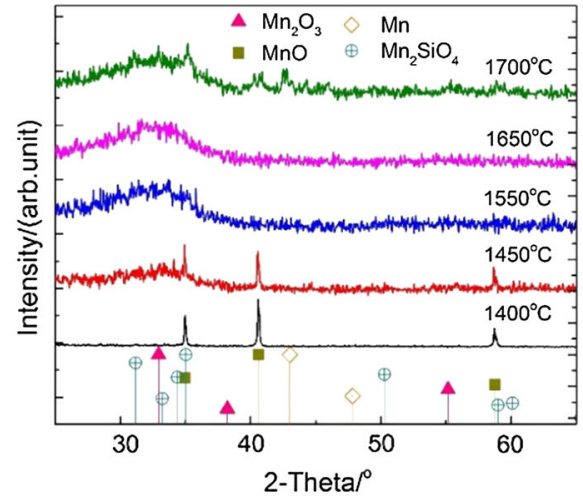

(c)

Fig. 9 XRD diffraction patterns of the fume in; a transition tube fume, $\mathbf{b}$ cooler fume, $\mathbf{c}$ filter fume

Table 4 Summary of fume particle phases at different collection sites, as identified by XRD

\begin{tabular}{|c|c|c|c|}
\hline & Transition tube fume & Cooler fume & Filter fume \\
\hline $1400{ }^{\circ} \mathrm{C}$ & $\mathrm{MnO}, \mathrm{Mn}_{3} \mathrm{O}_{4}, \mathrm{C}$ (graphite) & $\mathrm{MnO}$ & $\mathrm{MnO}$ \\
\hline $1450{ }^{\circ} \mathrm{C}$ & $\begin{array}{l}\mathrm{Mn}_{3} \mathrm{O}_{4}, \mathrm{Mn}_{2} \mathrm{SiO}_{4}, \mathrm{MnO} \\
\quad \text { ('graphite) }\end{array}$ & $\mathrm{MnO}$ & $\mathrm{MnO}$ \\
\hline $1500-1650{ }^{\circ} \mathrm{C}$ & $\mathrm{Mn}_{2} \mathrm{SiO}_{4}, \mathrm{Mn}_{3} \mathrm{O}_{4}, \mathrm{C}$ (graphite) & All amorphous & All amorphous \\
\hline $1700{ }^{\circ} \mathrm{C}$ & $\mathrm{Mn}_{2} \mathrm{SiO}_{4}, \mathrm{Mn}_{3} \mathrm{O}_{4}, \mathrm{C}$ (graphite) & $\begin{array}{l}\mathrm{Mn}_{2} \mathrm{SiO}_{4}, \mathrm{Mn}_{2} \mathrm{O}_{3}, \mathrm{MnO} \\
\quad \mathrm{Mn}\end{array}$ & $\begin{array}{l}\mathrm{Mn}_{2} \mathrm{SiO}_{4}, \mathrm{Mn}_{2} \mathrm{O}_{3}, \mathrm{MnO}, \\
\mathrm{Mn}\end{array}$ \\
\hline
\end{tabular}

in Table 4. Comparing the results from the three deposition sites, it becomes clear that the fume deposited in the relatively high-temperature zone of the transition tube is different from the other two sites. Small amounts of graphite were also present in almost all samples collected in the transition tube; it is believed to be caused by 


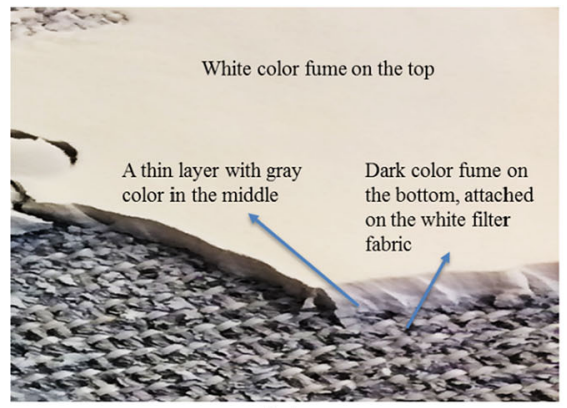

(a)

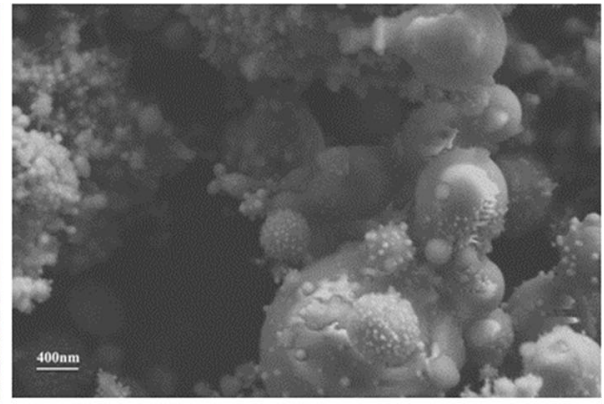

(b)

Fig. 10 Fume formed at the initial stages at the temperatures 1650 and $1700{ }^{\circ} \mathrm{C}$, a visual image of the fume, b dark fume morphology as observed by SEM

sooting resulting from the reverse Boudouard reaction of $\mathrm{CO}$ being cooled in the transition tube [6].

The particles collected in the filter and cooler are relatively similar, as the deposition temperatures are almost the same:

- At the relatively low temperature 1400 and $1450{ }^{\circ} \mathrm{C}$, only crystalline $\mathrm{MnO}$ is detected.

- At temperatures between 1500 and $1650{ }^{\circ} \mathrm{C}$, the fume is completely amorphous.

- At $1700{ }^{\circ} \mathrm{C}$, crystalline substances $\mathrm{Mn}_{2} \mathrm{SiO}_{4}, \mathrm{Mn}_{2} \mathrm{O}_{3}, \mathrm{MnO}$ and pure $\mathrm{Mn}$ are found in addition to amorphous particles.

The transition tube fume displays a different pattern, resulting from the higher deposition temperature:

- At the lowest temperature $1400{ }^{\circ} \mathrm{C}, \mathrm{MnO}$ dominates, but minor amounts of $\mathrm{Mn}_{3} \mathrm{O}_{4}$ are also found.

- At $1450{ }^{\circ} \mathrm{C}, \mathrm{Mn}_{3} \mathrm{O}_{4}$ and $\mathrm{MnO}$ are equally prevalent, in addition to oxides in the form of $\mathrm{Mn}_{2} \mathrm{SiO}_{4}$.

- At temperatures between 1500 and $1700{ }^{\circ} \mathrm{C}$, the fumes were identified as $\mathrm{Mn}_{2} \mathrm{SiO}_{4}$ and $\mathrm{Mn}_{3} \mathrm{O}_{4}$.

This is quite consistent with the calculated equilibrium calculations in Fig. 1 and the calculated vapour pressures in Fig. 5. $\mathrm{MnO}$ is the most prevalent manganese oxide in this temperature range, but it may oxidize further if the oxygen partial pressure is high enough during cooling.

Metallic Mn may become quenched before it is oxidized if the vapour pressure of $\mathrm{Mn}$ is very high. At high melt temperatures $\left(1650\right.$ and $\left.1700{ }^{\circ} \mathrm{C}\right)$, the fume formed at the initial stages of fume formation was visually different (much darker, see Fig. 10a) from the majority of the fume particles collected by the filter later during the experiment, suggesting that $\mathrm{Mn}$ vapourization, as shown in the reference experiment, is significant as soon as the melt reached high temperatures and before the gas flow started. The morphology of this dark colour fume is shown in Fig. 10b, 
which consists of larger spherical particles with a certain amount of small particles around, also indicating a particle growth process.

\section{Morphology and its Relation to Composition}

To elucidate the relationship between particle composition and shape, a transmission electron microscopy study (TEM) was carried out with typical filter fume samples obtained at 1400,1550 and $1700{ }^{\circ} \mathrm{C}$.

As identified in the SEM study, the morphology of filter fume at $1400{ }^{\circ} \mathrm{C}$ shows both irregular and spherical particles. The TEM diffraction results, see Fig. 11b, illustrate that the larger, spherical particles are amorphous, while the smaller, angular particles are all crystalline. From TEM EDS analysis, it was established that

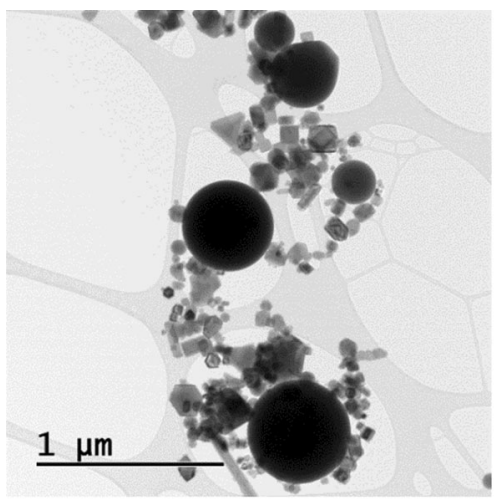

(a)

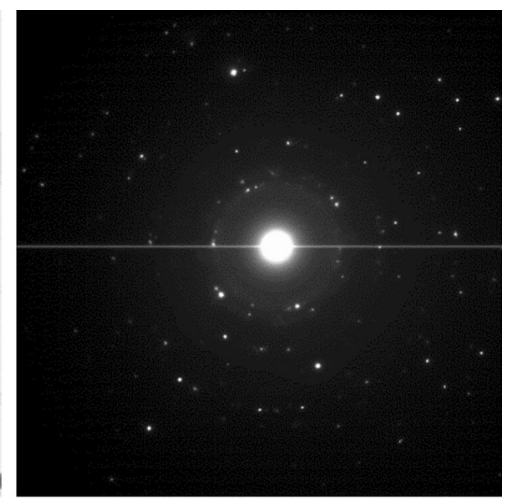

(b)

Fig. 11 Filter fume at $1400{ }^{\circ} \mathrm{C}$ : a TEM bright field image, b selected area electron diffraction pattern

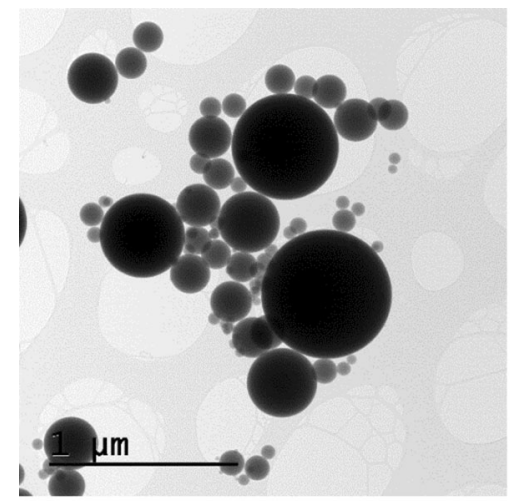

(a)

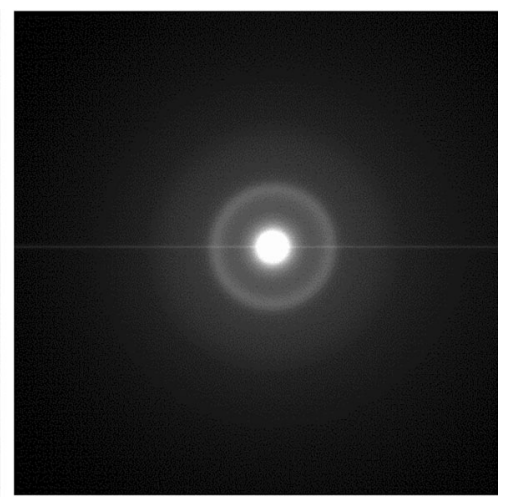

(b)

Fig. 12 Filter fume at $1550{ }^{\circ} \mathrm{C}$ : a TEM bright field image, b selected area electron diffraction pattern 


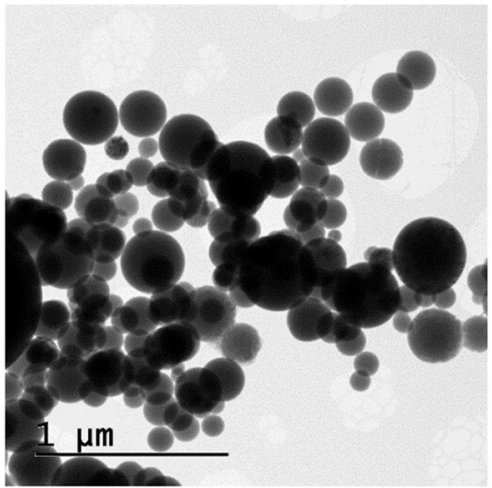

(a)

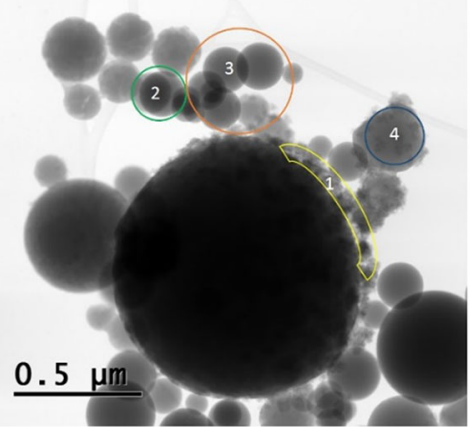

(c)

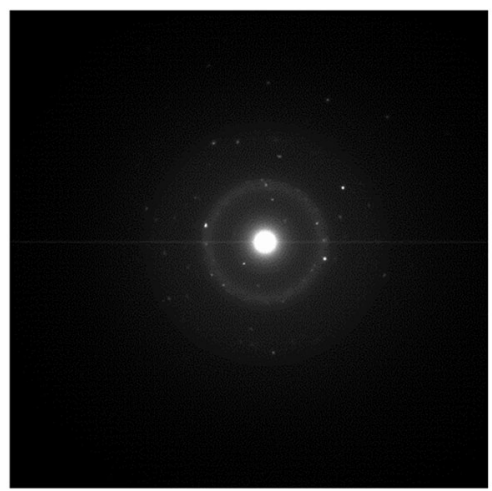

(b)

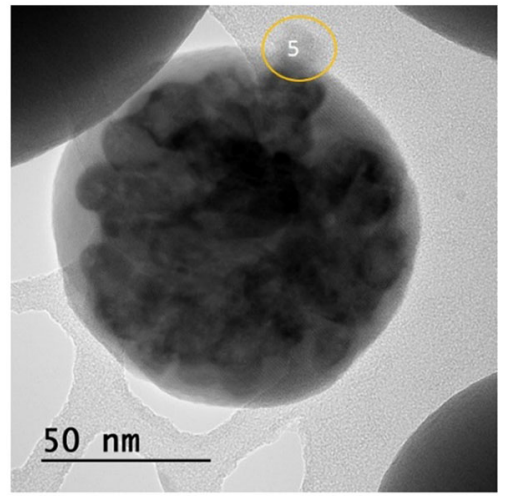

(d)

Fig. 13 Filter fume at $1700{ }^{\circ} \mathrm{C}$, a TEM bright field image, b selected area electron diffraction pattern, c and d some typical particles

all fume particles contain both $\mathrm{Mn}$ and $\mathrm{O}$, while only the spherical particles contain $\mathrm{Si}$ and $\mathrm{S}$.

Figure $12 \mathrm{a}$ shows a TEM image of filter fume at $1550{ }^{\circ} \mathrm{C}$. The particles are all spheres of various sizes and are all amorphous (see Fig. 12b). The elements are found evenly distributed over the entire mapping area.

The morphologies of fume at $1700{ }^{\circ} \mathrm{C}$ (Fig. 13) confirm the SEM results- the fume is all spherical particles with or without some smaller particles gathered on their periphery. Both crystalline and amorphous particles were found. Figure $13 \mathrm{c}, \mathrm{d}$ shows a range of particles. The particles marked 1 are $\mathrm{Mn}$, without $\mathrm{Si}$ or O content; some Ca-rich particle was found (2); the particles marked 3 are Mn-rich particles; the single spherical particle (marked 4) is rich in $\mathrm{Si}$ and $\mathrm{Mg}$. The single spherical particle in picture $\mathrm{d}$ is crystalline, in which the light colour part is rich in Si and the dark colour rich in $\mathrm{Mn}$. The small particle attached to the larger particle (marked as 5) contains only $\mathrm{Mn}, \mathrm{C}$ and $\mathrm{O}$. 


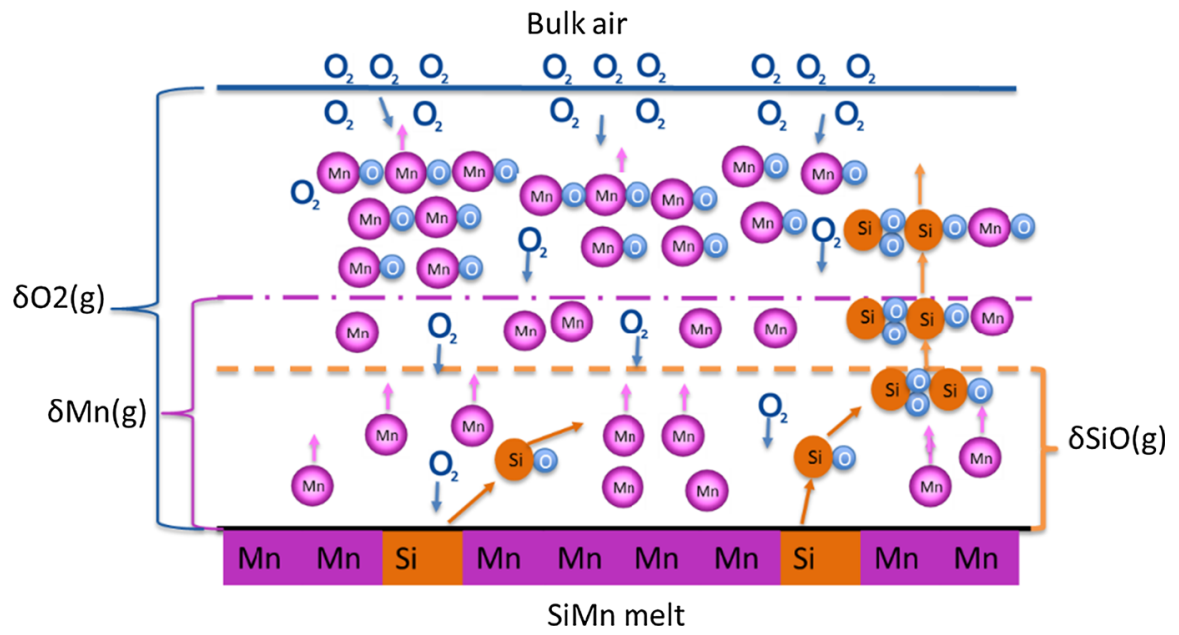

Fig. 14 Schematic description of fume formation from a liquid SiMn surface below $1500{ }^{\circ} \mathrm{C}$

\section{Fume Formation Mechanisms and Their Effects on Fume Morphology and Composition}

During the oxidation and fuming from a liquid SiMn surface, Mn has a high vapour pressure, whereas $\mathrm{Si}$ has a low vapour pressure. Si will, however, form gaseous $\mathrm{SiO}$ as described by Næss [18], which has a non-negligible partial pressure above the $\mathrm{SiMn}$ melt. The $\mathrm{O}_{2}$ boundary layer is expected to be thicker than the $\mathrm{SiO}$ boundary layer [18]. Mn vapour above a pure Mn melt will oxidize in a gas phase boundary layer as described by Turkogan [11].

For SiMn alloys, the relative thicknesses of the $\mathrm{O}_{2}(\mathrm{~g}), \mathrm{SiO}(\mathrm{g})$ and $\mathrm{Mn}(\mathrm{g})$ boundary layers have never been described in the literature. Therefore, the molecular reactions within these boundary layers and their kinetics are also unknown. Here, we take the liberty to outline some possible molecular reactions and their limiting factors. Further work will include atomic scale modelling to simulate these mechanisms under varying conditions. In the following, the denotation "clusters" describe molecular clusters.

As the alloy is heated, $\mathrm{Mn}$ is vapourized into a monoatomic Mn gas. During the oxidation process, oxygen in the jet-blown air will react with this $\mathrm{Mn}(\mathrm{g})$ to form $\mathrm{MnO}$ clusters (Eqs. 2, 3). These $\mathrm{MnO}$ clusters may further react with oxygen to form higher oxides, such as $\mathrm{M}_{3} \mathrm{O}_{4}$ (Eq. 4). The manganese oxides seem to crystallize into the angular/irregular particle shapes detected by electron microscopy.

$\mathrm{SiO}(\mathrm{g})$ molecules may form simultaneously, as oxygen diffuses down to the alloy surface and reacts with $\mathrm{Si}$ in the alloy. $\mathrm{SiO}$ clusters [22] may form inside the $\mathrm{SiO}$ boundary layer and then collect $\mathrm{Mn}$ and $\mathrm{O}_{2}$ atoms and/or $\mathrm{MnO}$ clusters to form larger clusters which may or may not crystallize upon solidification. The shape and amorphous nature of these particles indicate that they go through a liquid aerosol phase before they solidify into solid particulate matter. One detected, crystalline 


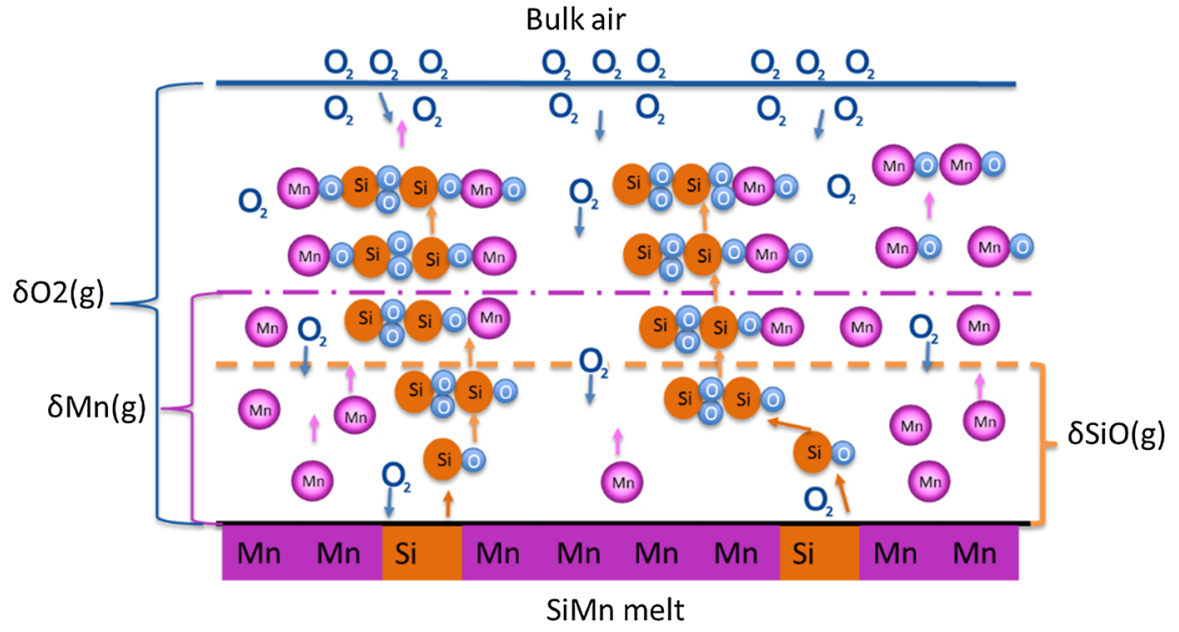

Fig. 15 Schematic description of fume formation from a liquid SiMn surface in between 1500 and $1600{ }^{\circ} \mathrm{C}$

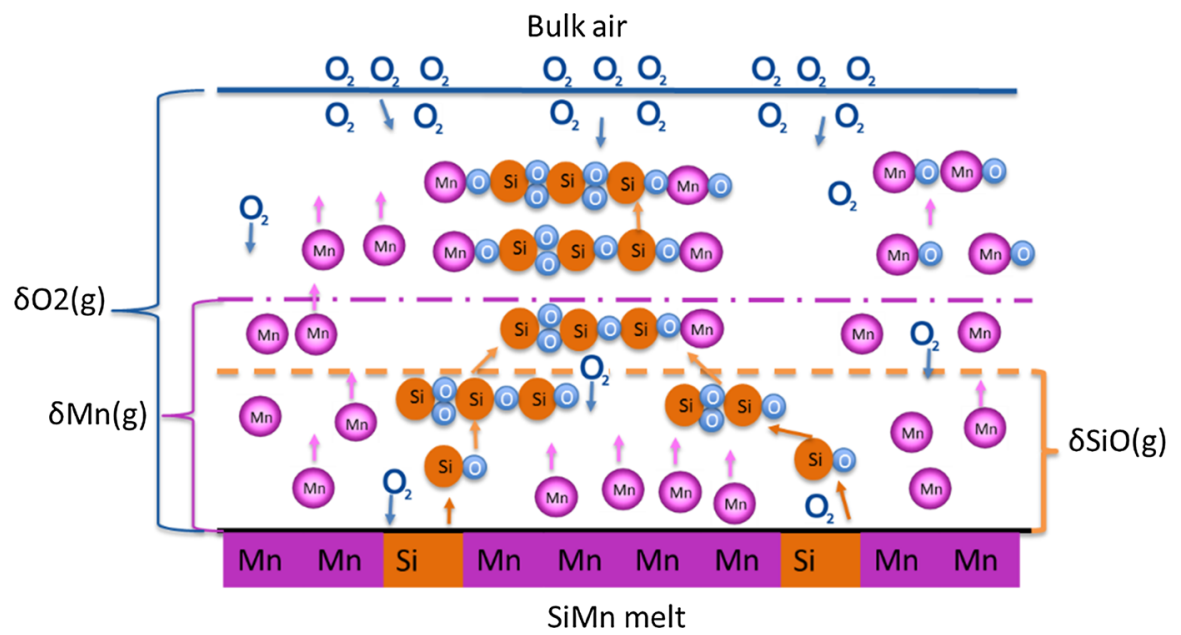

Fig. 16 Schematic description of fume formation from a liquid SiMn surface above $1600{ }^{\circ} \mathrm{C}$

stoichiometry (in addition to the amorphous $\mathrm{Mn} / \mathrm{Si}$-based particles) of this kind of particles is $\mathrm{Mn}_{2} \mathrm{SiO}_{4}$.

The formation of molecular clusters is schematically illustrated in Figs. 14, 15 and 16. 


\section{Low Temperature Range $\left(1400\right.$ and $\left.1450{ }^{\circ} \mathrm{C}\right)$}

In the lowest temperature range, the $\mathrm{SiO}$ pressure is low and $\mathrm{Mn}$ vapour is hence the main fume-forming gas, resulting in predominantly crystalline manganese oxide particles, as illustrated in Fig. 14. Oxygen diffusion towards the liquid metal surface is slow, thus, only very little $\mathrm{SiO}(\mathrm{g})$ forms, and thus only a limited number of $\mathrm{SiO}$ clusters and subsequent spherical $\mathrm{Mn}_{x} \mathrm{Si}_{y} \mathrm{O}_{z}$ particles are formed.

\section{Medium Temperature Range $\left(1500-1600^{\circ} \mathrm{C}\right)$}

In the medium temperature range, between 1500 and $1600{ }^{\circ} \mathrm{C}$, the oxygen diffusion onto the liquid metal surface is faster and the equilibrium of reaction 8 is shifted towards the right; more $\mathrm{SiO}$ gas is forming. This is illustrated in Fig. 15. The more the $\mathrm{SiO}$ cluster formed, the more the $\mathrm{Mn}_{x} \mathrm{Si}_{y} \mathrm{O}_{z}$-type oxides are generated. Such oxides are expected to solidify into spherical particles. In this temperature range, the $\mathrm{Mn}$ and Si fluxes are quantitatively closer and it appears that most of the $\mathrm{MnO}$ is reacted with $\mathrm{SiO}$ clusters, resulting in very few $\mathrm{Si}$-free particles.

\section{High Temperatures $\left(>1600{ }^{\circ} \mathrm{C}\right)$}

The gas velocity at the lance tip increases with temperature and so does the $\mathrm{Mn}$ vapour pressure. Some $\mathrm{Mn}(\mathrm{g})$ may diffuse to the outermost boundary layer. $\mathrm{SiO}(\mathrm{g})$ forms fast at these temperatures due to the relatively fast oxygen diffusion, forming $\mathrm{SiO}$ clusters and then capturing the surrounding species within the oxygen boundary layer, as well as the $\mathrm{Mn}(\mathrm{g})$ which has already diffused to the outermost boundary layer. Under these conditions, the $\mathrm{Mn}(\mathrm{g})$ may not have enough time to react with oxygen before it exits the crucible. During the transport to deposition in the cooler and the filter, part of the metallic Mn vapour may be exposed to more oxygen atmosphere and oxidize further. The rest of the $\mathrm{Mn}(\mathrm{g})$ will be quenched and condense as droplets onto the surfaces of the oxide particles. The oxidation mechanisms are schematically illustrated in Fig. 16.

\section{Conclusions}

Characteristic properties of the fume generated by an impinging air jet on a liquid standard grade silicomanganese alloy in the temperature range $1400-1700{ }^{\circ} \mathrm{C}$ have been established. The mass flux, morphology, composition and particle size distribution of the fume were evaluated. Three different temperature regimes for fume formation mechanisms were identified. Possible reaction kinetics were hypothesized to illustrate the fuming process at different temperatures. The following main conclusions were drawn from the study:

1. The mass flux of SiMn fume is dependent on melt temperature and increases with increasing temperature. The mass fluxes of $\mathrm{Si}$ and $\mathrm{Mn}$ species both increased with temperature, but the concentration of $\mathrm{Si}$ and $\mathrm{Mn}$ in the fumes 
differs. The oxidation process of Si is limited by the oxygen diffusion onto the liquid metal surface, which increases with temperature.

2. The morphology and phase composition of fume are heavily influenced by the presence of $\mathrm{SiO}(\mathrm{g})$ :

(a) Below $1500{ }^{\circ} \mathrm{C}$, the $\mathrm{SiO}$ gas formation is low and manganese oxides are the dominant species in the fume, forming mainly angular/irregular crystalline $\mathrm{MnO}$ fume particles.

(b) More $\mathrm{SiO}$ is generated at higher temperature (from 1500 to $1600{ }^{\circ} \mathrm{C}$ ), and liquid-origin spherical particles are formed together with some Mn oxide particles. The mass flux of Si from the SiMn melt is higher than what would be expected from an alloy composition perspective (as compared to pure $\mathrm{Mg}-\mathrm{Si}$ ), indicating that the presence of $\mathrm{Mn}$ enhances the oxidation of $\mathrm{Si}$.

(c) At temperatures above $1600^{\circ} \mathrm{C}$, when the $\mathrm{Mn}$ vapour pressure is very high, both $\mathrm{Mn}_{\mathrm{x}} \mathrm{Si}_{\mathrm{y}} \mathrm{O}_{\mathrm{z}}$-type particles and crystalline manganese oxide particles form. In addition, some metallic Mn fume is observed at this very high temperature.

3. Particle size distributions obtained by laser diffraction (LD) indicate the presence of particle agglomerates in the samples. These agglomerates stayed coherent after sample preparation by ultrasonication and were typically smaller than $2 \mu \mathrm{m}$. Protoparticle size distribution, on the other hand, was determined by SEM, and the protoparticles were smaller than $0.5 \mu \mathrm{m}$, with a median size of $0.1 \mu \mathrm{m}$. Understanding the "active" particle size in human fume exposure is a topic for future investigation.

Acknowledgements Funding from the Norwegian Ferroalloys Research Association (FFF), Saint Gobain, Washington Mills and the Norwegian Research Council through the DeMaskUs project (Contract 245216) is gratefully acknowledged. Sarel Johannes Francois Gates helped to carry out experimental work and performed the protoparticle size assessment, Elmira Moosavi Khoonsari and Kai Tang aided the FactSage modelling, Yingda Yu supported the SEM analysis, Irene Bragstad carried out the BET and LD analysis, and Per Erik Vullum facilitated the TEM analysis.

Open Access This article is distributed under the terms of the Creative Commons Attribution 4.0 International License (http://creativecommons.org/licenses/by/4.0/), which permits unrestricted use, distribution, and reproduction in any medium, provided you give appropriate credit to the original author(s) and the source, provide a link to the Creative Commons license, and indicate if changes were made.

\section{References}

1. IMnI and HATCH, IMnI LCA Summary Report View, (2015). http://www.manganese.org/images/ uploads/pdf/IMnI_LCA_Summary_Report_View_2015.pdf.

2. K. Gjønnes, et al., Analytical and Bioanalytical Chemistry 399, (3), 2011 (1011-1020).

3. S. Gunst, et al., Journal of Environmental Monitoring 2, (1), 2000 (6). 
4. I. Kero, et al., Journal of occupational and environmental hygiene 12, (1), 2015 (37-44).

5. S. Rencken, Analysis of secondary fume generation and capture during the tapping of high carbon ferromanganese, (University of Pretoria, 2013).

6. I. Kero et al., Fume formation from liquid ferromanganese, in 2015 sustainable industrial processing summit, (2015).

7. P. Cowx et al., The use of fine water sprays to suppress fume emissions when casting refined ferromanganese, in Infacon XIV, (1-4 June, Kyiv, 2015).

8. I. Kero and G. Tranell, Active oxidation and fume formation from liquid SiMn, in TMS Annual Meeting, (Wiley, Hoboken, 2016), pp. 77-84.

9. Y. Ma et al., Trace Elements Behavior During the Oxidation of Liquid SiMn Alloy, in 8th International Symposium on High-Temperature Metallurgical Processing, (Springer, Cham, 2017), pp. 215-224.

10. C. Wagner, Journal of Applied Physics 29, (9), 1958 (1295-1297).

11. E. T. Turkdogan, et al., The Journal of Physical Chemistry 67, (8), 1963 (1647-1654).

12. B. D. You, et al., Metals and Materials 5, (5), 1999 (497-502).

13. Y. E. Lee and L. Kolbeinsen, ISIJ International 45, (9), 2005 (1282-1290).

14. S. E. Olsen et al., Production of Manganese Ferroalloys, (Tapir Academic Press, Trondheim, 2007).

15. Factsage, Factsage 7.0, 2016. http://www.factsage.com/.

16. C. Gelain, et al., Oxidation of Metals 3, (2), 1971 (139-151).

17. J. W. Hinze and H. C. Graham, Journal of The Electrochemical Society 123, (7), 1976 (1066-1073).

18. M. K. Næss, et al., Oxidation of Metals 82, (5-6), 2014 (395-413).

19. M. K. Næss, et al., Oxidation of Metals 78, (5), 2012 (363-376).

20. M. K. Næss, et al., Oxidation of Metals 78, (3), 2012 (239-251).

21. E. Dingsøyr et al., Particle size and particle size distribution of microsilica and its relevance to technical applications, in The 5th European Symposium Particle Characterization, (Nurnberg, 1992).

22. A. C. Reber, et al., ACS Nano 2, (8), 2008 (1729-1737). 